\title{
STRATEGI PENGEMBANGAN USAHA MIKRO, KECIL DAN MENENGAH DALAM PENGUATAN EKONOMI KERAKYATAN (Studi Kasus pada Usaha Roti Maros di Kabupaten Maros)
}

\author{
Alyas ${ }^{1}$ dan Muhammad Rakib ${ }^{2}$ \\ ${ }^{1}$ Sekokah Tinggi Ilmu Ekonomi Yayasan Pendidikan Ujung Pandang \\ ${ }^{2}$ Universitas Negeri Makassar \\ E-mail: alyas_ismail@yahoo.com
}

\begin{abstract}
ABSTRAK. Penelitian ini bertujuan untuk mengetahui strategi pengembangan Usaha Mikro, Kecil dan Menengah (UMKM) dalam penguatan ekonomi kerakyatan pada Usaha Roti Maros di Kabupaten Maros. Pendekatan yang digunakan dalam penelitian ini adalah pendekatan kualitatif. Subjek penelitian yaitu pemilik usaha Roti Maros di Kabupaten Maros. Adapun teknik analisis data yang digunakan adalah teknik analisis kualitatif dan analisis SWOT. Dimana analisis kualitatif menggunakan teknik pengumpulan data triangulasi sedangkan analisis SWOT digunakan untuk mengidentifikasi berbagai faktor secara sistematis serta merumuskan strategi suatu perusahaan. Hasil penelitian ini menunjukkan bahwa strategi pengembangan usaha kecil dalam penguatan ekonomi kerakyatan pada usaha Roti Maros di Kabupaten Maros yang dapat digunakan yaitu pengembangan pasar dan produk, serta penetrasi pasar secara intensif dengan meningkatkan promosi, kualitas, serta inovasi produk Roti Maros.
\end{abstract}

Kata kunci: Strategi pengembangan, UMKM, penguatan ekonomi kerakyatan

\section{MICRO, SMALL AND MEDIUM ENTERPRISE DEVELOPMENT STRATEGY IN POWER ECONOMIC DEVELOPMENT (Case Study on Maros Bread Enterprise in Maros District)}

\begin{abstract}
This study aims to determine the strategy of micro, small and medium enterprises (UMKM) development in strengthening the populist economy in Maros Bakery in Maros Regency. The approach used in this study is a qualitative approach. The research subjects are the owner of Maros Bread business in Maros Regency. The data analysis techniques used are qualitative analysis techniques and SWOT analysis. Where the qualitative analysis using triangulation data collection techniques whereas SWOT analysis is used to identify various factors systematically as well as formulate a company's strategy. The results of this study indicate that the strategy of small-scale development in strengthening the populist economy in the business of Maros bread in Maros District that can be used is market and product development, As well as intensive market penetration by enhancing the promotion, quality, and innovation of Bakos Maros products.
\end{abstract}

Key words: development strategy, UMKM, economic strengthening of people

\section{PENDAHULUAN}

Salah satu strategi yang dilakukan oleh pemerintah dalam menopang pembangunan ekonomi yaitu memberdayakan dan menumbuhkan Usaha Mikro, Kecil dan Menengah (UMKM) sebagai basic pembangunan ekonomi kerakyatan. Sejarah telah menunjukkan bahwa UMKM di Indonesia tetap eksis dan berkembang meski terjadi krisis ekonomi.

Namun disisi lain, UMKM juga menghadapi banyak permasalahan, yaitu terbatasnya modal kerja, rendahnya kualitas Sumber Daya Manusia, dan kurangnya penguasaan ilmu pengetahuan dan teknologi. Permasalahan lain yang dihadapi UMKM yaitu keterkaitan dengan kurang jelasnya prospek usaha dan perencanaan, dan belum mantapnya visi dan misinya. Hal tersebut terjadi karena umumnya UMKM bersifat income gathering yaitu menaikkan pendapatan. Karakteristik tersebut dapat dilihat pada usaha mikro, kecil dan menengah sekarang ini, pada umumnya merupakan usaha milik keluarga, penggunaan teknologi yang masih relatif sederhana, kurang memiliki akses permodalan (bankable), dan tidak ada pemisahan modal usaha dengan kebutuhan pribadi.
Kondisi tersebut juga terjadi pada UMKM di wilayah Sulawesi Selatan khususnya pada wilayah Kabupaten Maros. Menurut Badan Pusat Statistik Maros terdapat 168 UMKM yang tersebar di 14 kecamatan di Kabupaten Maros. Dari 168 UMKM yang ada, mayoritas didominasi oleh usaha atau industri Roti Maros. Roti Maros merupakan salah satu oleh-oleh khas Kabupaten Maros yang menjadi daya tarik tersendiri bagi wisatawan lokal dari berbagai daerah yang sedang berkunjung ke Kota Makassar dan daerah lainnya. Akan tetapi penjualan roti maros kini mulai menurun terutama di kabupaten Maros. Saat ini usaha roti maros tersebut cenderung sepi pengunjung. Hal ini disebabkan para pelanggan yang umumnya adalah masyarakat yang melakukan perjalanan lintas kota baik menuju maupun kembali dari kota Makassar, lebih memilih untuk membeli jenis produk makanan lainnya untuk dijadikan sebagai oleh-oleh. Salah satu faktor yang menyebabkan hal tersebut adalah minimnya lahan parkir yang tersedia. Di samping itu varian rasa yang monoton juga menjadi faktor penghambat berkembangnya usaha Roti Maros di Kabupaten Maros.

Usaha untuk meningkatkan pembangunan ekonomi di pedesaan terutama memacu peningkatan 
pendapatan masyarakat, koperasi merupakan salah satu alternatif untuk memberdayakan ekonomi masyarakat. Supaya koperasi bisa tumbuh dan berkembang, maka faktor pendukung juga harus dikembangkan. Hasil pengamatan di lapangan ditemukan beberapa faktor pendukung pembangunan ekonomi daerah melalui pengembangan koperasi, antara lain: 1) potensi masyarakat; 2) pengusaha; 3) lembaga perkreditan; 4) instansi terkait; dan 5) koperasi sebagai badan usaha. (Almasdi Syahza, dkk. 2010).

Melihat hal tersebut para pelaku usaha hendaknya memiliki strategi dalam mengatasi masalah tersebut. Hal ini dikarenakan bahwa perkembangan industri roti yang ada di Kabupaten Maros memiliki prospek yang sangat baik dalam menunjang pertumbuhan ekonomi Kabupaten Maros.

Usaha Roti Maros penting dan cukup menarik untuk diteliti karena semakin berkembangnya industri roti yang ada di daerah tersebut maka dibutuhkan pula pasar yang cukup luas guna dapat memasarkan hasil produksi roti tersebut. Keuangan yang stabil juga diperlukan guna menjaga kestabilan industri roti tersebut. Setelah dikumpulkan berbagai isu strategis yang perlu untuk diperhatikan dalam pengembangan UMKM khususnya terhadap pengembangan produk Roti Maros, maka teridentifikasi kebutuhan akanaksespasar dan akses keuangan. Dalam rangka mengembangkan produk UMKM dalam hal ini produk Roti Maros perlu diteliti strategi apa saja yang dapat dilakukan guna mengembangkan usaha Roti Maros di Kabupaten Maros.

Berdasarkan uraian di atas, maka rumusan masalah dalam penelitian ini adalah strategi apa saja yang dapat dirumuskan dalam pengembangan usaha Roti Maros dalam penguatan ekonomi kerakyatan? Sedangkan tujuan penelitian ini adalah untuk merumuskan strategi pengembangan usaha Roti Maros dalam penguatan ekonomi kerakyatan.

\section{Strategi dan Pengembangan UMKM}

Strategi adalah cara pemimpin bisnis perusahaan merealisasikan filosofinya. Pengertian ini lebih menekankan pada strategi seharusnya berkaitan dengan keputusan besar yang dihadapi indvidu atau organisasi dalam melakukan bisnis yaitu keputusan yang menentukan kegagalan dan kesuksesan individu atau organisasi. (Kuncoro, 2005:265). Strategi sebagai suatu alat untuk mencapai tujuan jangka panjang. Selain itu strategi juga diartikan sebagai tindakan potensial yang membutuhkan keputusan manajemen tingkat atas dan sumber daya perusahaan dalam jumlah yang besar. (David, 2006:17)

Secara umum strategi merupakan pendekatan secara menyeluruh yang berkaitan dengan pelaksanaan ide/gagasan, perencanaan, dan pelaksanaansuatu kegiatan dalam kurun waktu tertentu. Strategi yang baik lebih menuntut adanya koordinasi tim kerja, memiliki tema, mengidentifikasi faktor pendukung yang sesuai dengan prinsip-prinsip pelaksanaan gagasan secara rasional, efisien dalam pendanaan, dan memiliki taktik untuk mencapai tujuan secara efektif. Strategi juga merupakan perangkat luas rencana organisasi untuk mengimplementasikan keputusan yang diambil demi mencapai tujuan organisasi. Strategi menjadi tiga kelompok yang dapat dipertimbangkan untuk diterapkan dalam suatu perusahaan yaitu: (1) Strategi perusahaan (corporate strategy), (2) Strategi bisnis atau strategi persaingan, dan (3) Strategi fungsional. (Sudaryanto, dkk., (2011:53)

\section{Pengembangan UMKM}

Pengembangan dapat diartikan sebagai suatu usaha untuk meningkatkan kemampuan konseptual, teoritis, teknis, dan moral individu sesuai dengan kebutuhan pekerjaan atau jabatan melalui pendidikan dan pelatihan. mengemukakan bahwa pengembangan UKM lebih diarahkan untuk menjadi pelaku ekonomi yang berdaya saing melalui perkuatan kewirausahaan dan peningkatan produktivitas yang didukung dengan upaya peningkatan adaptasi terhadap kebutuhan pasar, pemanfaatan hasil inovasi dan penerapan teknologi. (Afifuddin, 2010:180). Pengaruh dari pengembangan UMKM di Indonesia dan melihat peran serta pemerintah dalam meningkatkan pertumbuhan UMKM di Indonesia memiliki hasil positif, baik secara langsung maupun tidak langsung. (Tambunan, 2009:04)

Pengembangan UMKM pada hakikatnya merupakan tanggungjawab bersama antara pemerintah dan masyarakat. Dengan mencermati permasalahan yang dihadapi oleh UMKM, diperlukan upaya hal-hal seperti: (a) Penciptaan iklim usaha yang kondusif, (b) Bantuan Permodalan, (c) Perlindungan Usaha, (d) Pengembangan Kemitraan, (e) Pelatihan, (f) Mengembangkan Promosi, dan (g) Mengembangkan Kerjasama yang setara. (Hafsah 2004:43-44)

\section{Ekonomi Kerakyatan}

Ekonomi rakyat dapat dipahami dari dua pendekatan yaitu: pertama, pendekatan kegiatan ekonomi dari pelaku ekonomi berskala kecil (perekonomian rakyat). Pemberdayaan ekonomi rakyat dalam pendekatan ini dimaksudkan sebagai pemberdayaan pelaku ekonomi skala kecil. Kedua, pendekatan sistem ekonomi,yaitu demokrasi ekonomi atau sistem pembangunan yang demokratis (pembangunan partisipatif). Pemberdayaan ekonomi rakyat dalam pendekatan ini dimaksudkan untuk menerapkan prinsip-prinsip demokrasi dalam pembangunan. Ini berarti ekonomi rakyat merupakan suatu sistem ekonomi yang mengikutsertakan seluruh masyarakat dalam proses pembangunan sebagai pengerak pembangunan. Dengan demikian pendekatan kedua ini juga disebut sebagai ekonomi kerakyatan atau sistem ekonomi kerakyatan (A.Z. Yasin, 2002). 
Beberapa hal-hal yang harus diperhatikan pada sistem ekonomi yang mengarah pada ekonomi kerakyatan yaitu: (1) karakteristik daerah dan latar belakang keahlian mayoritas masyarakat setempat, (2) ekonomi berbasis rakyat yaitu kegiatan ekonomi yang sesuai dengan keahlian mayoritas masyarakat setempat, (3) karakteristik daerah yaitu meningkatkan nilai (value) dari potensi daerah, (4) peran pemerintah daerah yaitu mendorong tumbuhnya ekonomi rakyat melalui perbaikan sarana dan prasarana agar ekonomi rakyat tumbuh dan berkembang dengan pesat, (5) Potensi lokal/UMKM yaitu mendorong tumbuhnya industri berbasis potensi lokal/UMKM dengan pemberdayaan pembentukan koperasi atau unit produktif. (Zulkarnain, 2003: 98).

Ada beberapa penelitian terdahulu yang relevan dengan penelitian ini, diantaranya yaitu penelitian yang dilakukan oleh Supriatna, S dan Aminah, M. dengan judul "Analisis Strategi Pengembangan Usaha Kopi Luwak (Studi Kasus UMKM Careuh Coffee Rancabali-Ciwidey, Bandung)". Hasil penelitiannya menunjukan bahwafaktor-faktor internal dan eksternal yang berpengaruh terhadap perkembangan UMKM Careuh Coffee adalah kondisi finansial perusahaan, Sumber Daya Manusia, sikap konsumen, teknologi informasi dan lokasi. Penelitian ini menggunakan metode AHP, hasil alternatif strategi yang dapat dilakukan oleh UMKM Careuh Coffee di antaranya penguatan SDM pemasaran. Strategi ini bertujuan untuk membangun fondasi yang kuat agar UMKM Careuh Coffee berjalan dengan baik. Kemudian strategi selanjutnya berturut-turut adalah startegi integrasi ke depan, optimalisasi digital marketing serta menerapkan promosi bellow-the-line marketing. Sedangkan penelitian yang dilakukan oleh Primawardana, T.\&Indriyani, R. dengan judul'"Strategi Pengembangan Usaha Pada "Yulia Bakery" Sidoarjo". Hasil penelitiannya menunjukkan bahwa Yulia bakery memiliki beberapa kekuatan, kelemahan, peluang dan ancaman yang saling berkaitan. Strategi pengembangan usaha yang sesuai dengan hasil analisis SWOT. Strategi yang dapat digunakan Yulia Bakery adalah penetrasi pasar, pengembangan pasar, dan pengembangan produk. Pengembangan usaha yang dilakukan meliputi beberapa aspek, seperti pemasaran, keuangan, produksi dan SDM.

\section{METODE}

Penelitian ini dilakukan di Kabupaten Maros pada usaha Roti Maros. Teknik pemilihan lokasi dilakukan secara sengaja dengan terlebih dahulu melakukan observasi untuk mengetahui potensi-potensi agro ekonomi apa saja yang bisa dikembangkan di Kabupaten Maros, kemudian dipilih salah satu potensi yang menonjol diantara yang ada yaitu Usaha Roti Maros, Penelitian dilakukan pada bulan Juli 2016 sampai dengan Agustus 2016. Adapun yang menjadi informan dari penelitian ini adalah para pemilik usaha Roti Maros di Kabupaten
Maros. Sumber data dari penelitian ini terdiri berupa hasil wawancara terhadap para pemilik usaha roti maros dan data-data yang diperoleh dari situs-situ internet, jurnal dan artikel lain yang berkaitan dengan penelitian ini. Teknik pengumpulan data yang digunakan dalam penelitian ini yaitu observasi, wawancara, dan dokumentasi. Teknik analisis data yang digunakan dalam penelitian ini adalah Analisis kualitatif dan analisis SWOT.

\section{HASIL DAN PEMBAHASAN}

\section{Faktor Yang Mempengaruhi Strategi Pengembangan UMKM dalam Penguatan Ekonomi Kerakyatan}

\section{Faktor Internal (Kekuatan dan Kelemahan)}

Ada beberapa faktor internal yang diidentifikasi menjadi kekuatan strategi pemgembangan UMKM khususnya usaha Roti Maros dalam penguatan ekonomi kerakyatan, yaitu: 1) Kenyamanan tempat dan lokasi yang strategis, 2) Harga yang relatif terjangkau, 3) Bahan baku yang selalu tersedia, 4) Variasi rasa Roti Maros, 5) Aneka macam produk pendamping yang ditawarkan, dan 6) Komunikasi dan keakraban karyawan yang terjalin baik. Setelah diidentifikasi, ada beberapa juga faktor internal yang menjadi kelemahan strategi pengembangan UMKM khususnya usaha Roti Marosd alam penguatan ekonomi kerakyatan, yaitu: (1) Modal yang terbatas, (2) Sistem manajemen usaha yang masih lemah, (3) Kualitas dan kuantitas SDM yang terbatas, (4) Pemasaran (promosi) yang belum intensif, dan (5) Alat produksi pendukung masih terbatas.

\section{Faktor Eksternal (Peluang dan Ancaman)}

Faktor eksternal yang menjadi peluang strategi pengembangan UMKM khususnya usaha Roti Maros di Kabupaten Maros yaitu: (1) Dukungan dari pemerintah, (2) Perkembangan teknologi dan informasi, (3) Ekspansi (perluasan) usaha, dan (4) Hubungan baik dan Loyalitas pelanggan. Sedangkan yang menjadi ancaman strategi pengembangan UMKM khususnya usaha Roti Maros di Kabupaten Maros yaitu: (1) Harga bahan baku yang tidak stabil, (2) Munculnya pesaing baru dengan produk yang sama, (3) Munculnya Kompetitor yang menawarkan produk yang berbeda, dan (4) Lokasi antar usaha yang saling berdekatan.

\section{Matriks Internal Factor Evaluation (IFE) dan External Factor Evaluation (EFE)}

Tabel 2 menunjukkan bahwa nilai tertinggi untuk aspek yang menjadi peluang adalah dukungan dari pemerintah $(0,8)$ dan hubungan baik serta loyalitas pelanggan $(0,8)$, perkembangan teknologi $(0,6)$, dan ekspansi usaha $(0,15)$. Sehingga dapat dikatakan bahwa faktor dukungan dari pemerintah dan hubungan baik serta loyalitas pelanggan merupakan dapat dijadikan peluang utama dalam mengembangkan usaha. 


\section{Matriks Internal Factor Evaluation (IFE)}

Tabel 1. Evaluasi Faktor Internal Usaha Roti Marosdi Kabupaten Maros

\begin{tabular}{|c|c|c|c|c|}
\hline No & Faktor Internal & $\begin{array}{c}\text { Bobot } \\
\text { (a) }\end{array}$ & $\begin{array}{c}\text { Rating } \\
\text { (b) }\end{array}$ & $\begin{array}{c}\text { Nilai } \\
\text { (a)x(b) }\end{array}$ \\
\hline \multirow[t]{6}{*}{1.} & Kekuatan $(+)$ & & & \\
\hline & 1. Kenyamanan Tempat dan Lokasi yang strategis & 0,15 & 4 & 0,6 \\
\hline & 2. Harga yang relatif terjangkau & 0,05 & 2 & 0,1 \\
\hline & 3. Variasi rasa Roti Maros & 0,15 & 3 & 0,45 \\
\hline & 4. Aneka macam produk pendamping yang ditawarkan & 0,05 & 3 & 0,15 \\
\hline & 5. Komunikasi dan keakraban karyawan yang terjalin baik & 0,1 & 4 & 0,4 \\
\hline \multirow[t]{7}{*}{2.} & Kelemahan (-) & & & \\
\hline & 1. Modal yang terbatas & 0,1 & 3 & 0,3 \\
\hline & 2. Sistem manajemen usaha yang masih lemah & 0,05 & 3 & 0,15 \\
\hline & 3. Kualitas dan kuantitas SDM yang terbatas & 0,15 & 4 & 0,6 \\
\hline & 4. Pemasaran (promosi) yang belum intensif & 0,15 & 4 & 0,6 \\
\hline & 5. Alat produksi pendukung masih terbatas & 0,05 & 2 & 0,1 \\
\hline & Jumlah & 1,00 & & 3,45 \\
\hline
\end{tabular}

\section{Matriks External Factor Evaluation (EFE)}

Tabel 2. Evaluasi Faktor Eksternal Usaha Roti Maros di Kabupaten Maros

\begin{tabular}{|c|c|c|c|c|}
\hline No. & Faktor Eksternal & $\begin{array}{l}\text { Bobot } \\
\text { (a) }\end{array}$ & $\begin{array}{l}\text { Rating } \\
\text { (b) }\end{array}$ & $\begin{array}{c}\text { Nilai } \\
\text { (a) } \mathrm{x}(\mathrm{b})\end{array}$ \\
\hline \multirow[t]{5}{*}{1} & Peluang $(+)$ & & & \\
\hline & 1. Dukungan dari pemerintah & 0,2 & 4 & 0,8 \\
\hline & 2. Perkembangan teknologi dan informasi & 0,15 & 4 & 0,6 \\
\hline & 3. Ekspansi (perluasan) usaha & 0,05 & 3 & 0,15 \\
\hline & 4. Hubungan baik dan Loyalitas pelanggan & 0,2 & 4 & 0,8 \\
\hline \multirow[t]{6}{*}{2} & Ancaman (-) & & & \\
\hline & 1. Harga bahan baku yang tidak stabil & 0,15 & 4 & 0,6 \\
\hline & 2. Munculnya pesaing baru dengan produk yang sama & 0,1 & 3 & 0,3 \\
\hline & $\begin{array}{l}\text { 3. Munculnya Kompetitor yang menawarkan produk yang } \\
\text { berbeda (produk subtitusi) }\end{array}$ & 0,05 & 3 & 0,15 \\
\hline & 4. Lokasi antar Toko yang saling berdekatan & 0,1 & 2 & 0,2 \\
\hline & Jumlah & 1,00 & & 3,6 \\
\hline
\end{tabular}

Sementara untuk faktor yang menjadi ancaman dengan nilai tertinggi adalah harga bahan baku yang tidak stabil $(0,6)$, munculnya pesaing baru dengan produk yang sama $(0,3)$, lokasi toko yang saling berdekatan $(0,2)$, dan munculnya kompetitor dengan produk yang berbeda. Faktor dengan nilai tertinggi ini menandakan bahwa faktor tersebut merupakan anacaman serius bagi keberlangsungan usaha kedepannya.

\section{Analisis matriks Internal dan Eksternal (I-E)}

Matriks I-E (Internal-Eksternal) dihasilkan melalui penggabungan informasi yang diperoleh dari tabel EFE dan IFE untuk mendapatkan informasi mengenai posisi perusahaan guna mempermudah dalam pemberian alternatif strategi. Nilai matriks EFE sebesar 3,6 menunjukkan Usaha Roti Maros memiliki kemampuan yang tinggi dalam memanfaatkan peluang dan menghindari ancaman yang ada. Sedangkan nilai matriks IFE sebesar 3,45 menunjukkan Usaha Roti Maros memiliki faktor internal yang tergolong tinggi dalam memanfaatkan kekuatan yang dimiliki untuk mengatasi kelemahan internal yang ada.
Berdasarkan nilai matriks EFE dan IFE tersebut, didapatkan posisi persaingan Usaha Roti Maros pada kuadran I. Pada posisi tersebut, strategi yang terbaik dilakukan adalah strategi pertumbuhan Usaha Roti Maros, pengembangan pasar dan produk, serta penetrasi pasar secara intensif dengan meningkatkan promosi, kualitas, serta inovasi produk Roti Maros. Hal ini sejalan dengan hasil penelitian Primawardana, T. \& Indriyani, R. (2015) pada Usaha Roti "Yuliana Bakery" Sidoarjo.

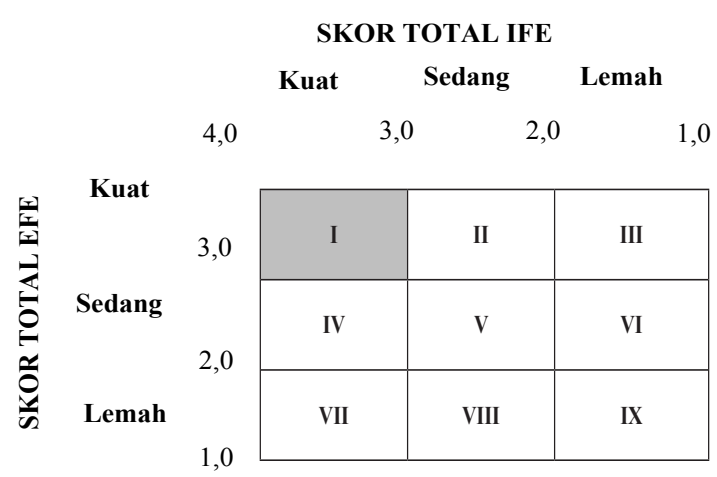

Gambar 1. Matriks I-E UsahaRoti Maros 


\section{Matriks Analisis SWOT}

\begin{tabular}{|c|c|c|}
\hline $\begin{array}{l}\text { Faktor } \\
\text { Eksternal }\end{array}$ & $\begin{array}{l}\text { Strengths (S) } \\
\text { 1. Kenyamanan Tempat dan Lokasi yang strategis } \\
\text { 2. Harga yang relatif terjangkau } \\
\text { 3. Bahan baku yang selalu tersedia } \\
\text { 4. Variasi rasa Roti Maros } \\
\text { 5. Aneka macam produk pendamping yang } \\
\quad \text { ditawarkan } \\
\text { 6. Komunikasi dan keakraban karyawan yang } \\
\quad \text { terjalin baik }\end{array}$ & $\begin{array}{l}\text { Weakness (W) } \\
\text { 1. Modal yang terbatas } \\
\text { 2. Sistem manajemen usaha yang masih } \\
\text { lemah } \\
\text { 3. Kualitas dan kuantitas SDM yang terbatas } \\
\text { 4. Pemasaran(promosi) yang belum intensif } \\
\text { 5. Alat produksi pendukung masih terbatas }\end{array}$ \\
\hline $\begin{array}{l}\text { Opportuny (O) } \\
\text { 1. Dukungan dari pemerintah } \\
\text { 2. Perkembangan teknologi dan } \\
\text { informasi } \\
\text { 3. Ekspansi (perluasan) usaha } \\
\text { 4. Hubungan baik dan Loyalitas } \\
\text { pelanggan }\end{array}$ & $\begin{array}{l}\text { Strategi SO } \\
\text { 1. Melakukan inovasi dan variasi produk dalam } \\
\text { menarik dan menumbuhkan loyalitas pelanggan } \\
\text { serta menunjang perluasan usaha kedepan. } \\
\text { pelanggan (S4, S5, W3, dan W4) } \\
\text { 2. Meningkatkan potensi usaha dengan } \\
\text { memanfaatkan lokasi yang strategis serta } \\
\text { perkembangan akses teknologi dan informasi. } \\
\text { (W1 dan O2) } \\
\text { 3. Dengan adanya dukungan pemerintah proses } \\
\text { produksi dan pejualan dapat dimaksimalkan, } \\
\text { serta kestabialn harga jual dapat terjaga. } \\
\text { (S2,S3,S6, dan W1) }\end{array}$ & $\begin{array}{l}\text { Strategi WO } \\
\text { 1. Keterbatasan modal serta alat penunjang } \\
\text { produksi dapat diatasi dengan adanya } \\
\text { bantuan dana dari pemerintah (W1 dan } \\
\text { O1) } \\
\text { 2. Memperbaiki dan memperketat sistem } \\
\text { manajemen serta rekruitmen karyawan } \\
\text { agar tidak mengahambat kemajuan usaha. } \\
\text { (W2,W3, dan O3) } \\
\text { 3. Memaksimalkan penggunaan media } \\
\text { promosi seperti media cetak dan } \\
\text { elektronik guna menjangkau lebih banyak } \\
\text { konsumen. (W4, O2, dan O4) }\end{array}$ \\
\hline $\begin{array}{l}\text { Threats }(\mathbf{T}) \\
\text { 1. Harga bahan baku yang tidak } \\
\text { stabil } \\
\text { 2. Munculnya pesaing baru } \\
\text { dengan produk yang sama } \\
\text { 3. Munculnya Kompetitor yang } \\
\text { menawarkan produk yang } \\
\text { berbeda } \\
\text { 4. Lokasi antar Toko yang } \\
\text { saling berdekatan }\end{array}$ & $\begin{array}{l}\text { Strategi ST } \\
\text { 1. Menjaga dan meningktakan kepuasan pelanggan } \\
\text { melalui konsistensi kualitas, variasi dan inovasi } \\
\text { produk yang ditawarkan. (S3,S4,S5,T2, dan T3) } \\
\text { 2. Memanfaatkan lokasi yang startegis serta } \\
\text { memberikan promo khusus bagi pelanggan guna } \\
\text { menarik pelanggan.(S1,S2,S6,T1,dan T2) }\end{array}$ & $\begin{array}{l}\text { Upaya peningkatan sistem manaejemen } \\
\text { usaha, kualitas SDM, pola pemasaran yang } \\
\text { intensif, dan teknologi produksi diperlukan } \\
\text { dalam mengatasi masalah yang ada serta } \\
\text { persaingan usaha yang ada. (W1-W5 dan } \\
\text { T1-T4) }\end{array}$ \\
\hline
\end{tabular}

\section{Tabel 3. Matriks SWOT Strategi Pengembangan Usaha Roti Maros di Kabupaten Maros}

Berdasarkan hasil analisis SWOT dan nilai matriks EFE (External Factor Evaluation) dan IFE (Internal Factor Evaluation)dapat diketahui posisi pengembangan Usaha Roti Maros di Kabupaten Maros pada kuadran I. Pada posisi tersebut, strategi yang terbaik dilakukan adalah strategi pertumbuhan. Usaha Roti Maros di Kabupaten Maros pengembangan pasar dan produk, serta penetrasi pasar secara intensif dengan meningkatkan promosi, kualitas, serta inovasi produk Roti Maros. Secara keseluruhan dari analisis faktor-faktor tersebut, dapat dirumuskan beberapa strategi pengembangan usaha seperti berikut ini.

\section{1) Lokasi yang strategis}

Lokasi merupakan letak atau tempat dimana suatu usaha tersebut dijalankan. Menurut Kotler (2008:51) "Salah satu kunci menuju sukses adalah lokasi, lokasi dimulai dengan memilih komunitas". Keputusan ini sangat bergantung pada potensi pertumbuhan ekonomis dan stabilitas, persaingan, iklim politik, dan sebagainya.Lokasi sangat mempengaruhi angka penjualan usaha Roti Maros di Kabupaten Maros. Semakin dekat dengan jalan poros maka semakin besar peluang suatu usaha untuk dapat berkembang.

\section{2) Memaksimalkan Bantuan Modal dari Pemerintah}

Selain dari modal pribadi, modal juga didapat dari pemerintah berupa Kredit Usaha Rakyat (KUR).
Pemerintah juga ikut bertanggungjawab dalam keberlangsungan usaha mikro kecil dan menengah. Hal ini sejalan dengan beberapa pendapat para ahli, seperti yang dikemukakan oleh Hafsah (2004:4344) bahwa pengembangan UKM pada hakikatnya merupakan tanggungjawab bersama antara pemerintah dan masyarakat.

3) Meningkatkan kapasitas penjualan.

Adanya faktor kekuatan berupa ketersidiaan bahan baku yang stabil bisa digunakan untuk memanfaatkan peluang yang ada yaitu membaiknya kondisi perekonomian Indonesia diikuti meningkatnya daya beli masyarakat, serta adanya kemajuan teknologi dan bantuan dari pemerintah, peluang ini bisa diambil oleh UKM Roti Maros di Kabupaten Maros, salah satunya dengan meningkatkan kapasitas penjualan.

4) Memaksimalkan jumlah pelanggan tetap.

Dengan memanfaatkan kekuatan internal berupa faktor kemampuan memenuhi permintaan sesuai dengan kebutuhan konsumen, mampu menjaga kontinuitas untuk memenuhi permintaan yang ada, sudah mempunyai pelanggan tetap tapi masih sedikit jumlahnya, dan terjalinnya hubungan yang baik dengan semua pelanggan bisa menjadi modal untuk memanfaatkan peluang yang ada yaitu hubungan baik dengan pembeli/pelanggan, dengan memanfaatkan kepercayaan yanga ada 
bisa ditingkatkan menjadi pelanggan tetap usaha Roti Maros Kabupaten Maros.

5) Melakukan inovasi dan variasi produk

Banyaknya kompetitor yang bermunculan mendorong perlunya sebuah inovasi dan variasi produk. Hal ini diperlukan guna memaksimalkan penjualan dan menarik perhatian pelanggan. Inovasi ini diantaranya adalah dengan melakukan variasi rasa Roti Maros, dan menambah ragam variasi produk yang ditawarkan ditoko.

6) Pemanfaatan teknologi dalam melakukan promosi yang intensif

Dengan melakukan promosi lebih agresif, usaha Roti Maros di Kabupaten Maros bisa mengatasi kelemahan tempat yang kurang strategis karena lokasinya jauh dari jalan utama, juga kelemahan belum dilakukannya promosi secara agresif. Sehingga dengan dilakukannya promosi akan lebih memaksimalkan dan memanfaatkan potensi lokasi yang startegis. Tidak hanya menjadi penonton saja diantara pengusaha yang lain, tetapi bisa menjadi pemain yang mampu mengambil peluang yang ada.

7) Penerapan sistem manajemen usaha terutama dalam segi pencatatan keuangan dan administrasi Manajemen usaha merupakan unsur penting dalam menjalankan dan menjaga keberlangsungan usaha. Beberapa pemilik usaha Roti Maros belum melakukan sistem manajemen usaha yang baik, terutama menyangkut sistem pencatatan keuangan ataupun administrasi yang ada menjadi kelemahan utama yang harus segera diatasi. Pagaya (2013) menyatakan bahwa dengan melakukan pencatatan yang baik akan diketahui secara tertulis apakah biaya-biaya yang dikeluarkan oleh UKM sudah efisien, dan juga bisa diketahui pos-pos biaya apa saja yang tidak efisien sehingga margin usaha Roti Maros bisa ditingkatkan.

8) Peningkatan kualitas SDM guna memaksimalkan kapasitas produksi.

Terjaganya hubungan baik dan loyalitas dengan semua karyawan, serta motivasi yang tinggi perlu dimaksimalkan lagi dengan melakukan upaya peningkatan keterampilan karyawan melalui pendidikan dan pelatihan. Wahyuningtias (2011) mengemukakan bahwa dengan adanya peningkatan kualitas karyawan ini diharapkan juga dapat bersinergi dengan peningkatan kapasitas produksi.

\section{SIMPULAN}

Faktor yang menjadi kekuatan dari usaha Roti Maros meliputi kenyamanan tempat dan lokasi yang strategis, harga yang relatif terjangkau, variasi rasa Roti Maros, aneka macam produk pendamping yang ditawarkan, serta komunikasi dan keakraban karyawan yang terjalin baik. Sedangkan, faktor yang menjadi kelemahan meliputi modal yang terbatas, sistem manajemen usaha yang masih lemah, kualitas dan kuantitas SDM yang terbatas, pemasaran (promosi) yang belum intensif, serta alat produksi pendukung masih terbatas. Adapun faktor yang menjadi peluang usaha Roti Maros ini meliputi dukungan dari pemerintah, perkembangan teknologi dan informasi, ekspansi (perluasan) usaha, serta hubungan baik dan loyalitas pelanggan. Sedangkan yang menjadi faktor ancaman meliputi harga bahan baku yang tidak stabil, munculnya pesaing baru dengan produk yang sama, munculnya kompetitor yang menawarkan produk yang berbeda (produk subtitusi), serta lokasi antar usaha yang saling berdekatan

Hasil identifikasi faktor internal (kekuatan dan kelemahan) dan faktor eksternal (peluang dan ancaman) dapat dirumuskan beberapa strategi pengembangan usaha Roti Maros, diantaranya yaitu lokasi yang strategis, memaksimalkan bantuan modal dari Pemerintah, meningkatkan kapasitas penjualan, memaksimalkan jumlah pelanggan tetap, melakukan inovasi dan variasi produk, pemanfaatan teknologi dalam melakukan promosi yang intensif, penerapan sistem manajemen usaha terutama dalam segi pencatatan keuangan dan administrasi, dan peningkatan kualitas SDM guna memaksimalkan kapasitas produksi.

\section{DAFTAR PUSTAKA}

Afifuddin. 2010. Pengantar Administrasi Pembangunan. Bandung: CV Alfabeta.

Almasdi Syahza Dan Henny Indrawati, 2010. Pemberdayaan Koperasi Berbasis

Agribisnis di Daerah Pedesaan. Sosiohumaniora, Vol. 12, No. 3, 2010: 207-220

A. Z. Yasin, F. 2002. Petani, Usaha Kecil Dan Koperasi Berwawasan Ekonomi Kerakyatan. Pekanbaru: Unri Press.

David, F. R.2006. Manajemen Strategi; Konsep Edisi Kesepuluh. Jakarta: Salemba Empat.

Hafsah, M. J. 2004. Upaya Pengembangan Usaha Mikro, Kecil dan Menengah (UMKM). Jurnal Infokop. Nomor 25 Tahun XX.

Kotler, P. 2008. Manajemen pemasaran, jilid 1. Jakarta: PT. Indeks Kelompok Gramedia.

Kuncoro, M. 2005. Strategi Bagaimana Meraih Keunggulan Kompetitif. Jakarta: Erlangga.

Pagaya, M. D. 2013. Pengelolaan Dan Pengembangan Usaha Bakery Pada UD Lima Roti di Ambon. Jurnal Ekonomi Bisnis. Vol. 1 No. 3 (2013), h. 1-9.

Primawardana, T.\&Indriyani, R. 2015. Strategi Pengembangan Usaha Pada "Yulia Bakery" Sidoarjo. AGORA. Vol. 3, No. 2, (2015). h. 364-372. 
Supriatna, S dan Aminah, M. 2014. “Analisis Strategi Pengembangan Usaha Kopi Luwak (Studi Kasus UMKM Careuh Coffee RancabaliCiwidey, Bandung)". Jurnal Manajemen dan Organisasi. Vol V, No 2 (2014). h. 227-243.

Sudaryanto, Ragimun, dan Rahma R. 2011. Strategi pemberdayaan UMKM menghadapi pasar bebas ASEAN. Universitas Negeri Jember.

Tambunan, T. 2009. UMKM di Indonesia. Bogor: Ghalia.
Wahyuningtias,D. 2011. "Perencanaan Strategik Usaha Kecil Menengah Jenis Usaha Kue dan Roti”. Jurnal Ekonomi dan Bisnis. Vol. 2 No. 1 (2011), h. 564-570.

Zulkarnain. 2003. Membangun Ekonomi Rakyat:Persepsi Tentang Pemberdayaan Ekonomi Rakyat. Yogyakarta: Adicita Karya Nusa. 